\title{
Pengenalan Alat Peraga Dasar Matematika Kepada Siswa Sekolah Dasar (SD)
}

\author{
Besse Arnawisuda Ningsi, Irvana Arofah \\ Universitas Pamulang \\ dosen00351@unpam.ac.id
}

Received: $10^{\text {th }}$ May $2020 \mid$ Accepted: $1^{\text {st }}$ December 2020 | Published: $30^{\text {th }}$ January 2021

\section{Key word:}

Mathematics;

Learning

Property;

Teaching aid

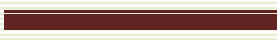

\section{Kata Kunci}

Matematika;

Alat Peraga;

Pembelajaran

\section{Abstract}

Community service carried out by a team of lecturers at Pamulang University in Pamulang sub-district, South Tangerang city in an effort to increase knowledge of mathematical concepts targeting elementary school (SD) students and students. The activities carried out were divided into 3 stages, the first stage: first giving a test (pre-test) to students for the purpose of knowing students' knowledge of mathematics teaching aids, the second stage providing assistance in introducing teaching aids and understanding mathematical arithmetic concepts with the help of mathematical props, and the third stage is evaluating by giving a test (post-test) to determine the results of the treatment in the second stage. The props used in this activity are nomograph props, balance props for walking cars. Each of these teaching aids provides an understanding of mathematical arithmetic concepts in the arithmetic operations of addition, subtraction, multiplication and division. From the results of the post-test carried out, it was seen that there was an increase in students' knowledge of the props and understanding of the concept of solving mathematical arithmetic operations in the form of addition, subtraction, multiplication and division operations after being given understanding with the help of mathematical teaching aids.

\section{Abstrak}

Pengabdian masyarakat yang dilaksanakan oleh tim dosen Universitas Pamulang di kecamatan Pamulang kota Tangerang Selatan dalam upaya peningkatan pengetahuan konsep-konsep matematika dengan sasaran siswa dan siswi Sekolah Dasar (SD). Kegiatan yang dilaksanakan dibagi menjadi 3 tahapan, tahap pertama: pertama pemberian tes (pre-test) kepada siswa untuk yang bertujuan untuk mengetahui pengetahuan siswa terhadap alat peraga matematika, tahap kedua memberikan pendampingan pengenalan alat peraga dan pemahaman konsep berhitung matematika dengan bantuan alat peraga matematika, dan tahap ketiga melakukan evaluasi dengan cara pemberian tes (post-test) untuk mengetahui hasil dari pemberian perlakuan pada tahap kedua. Alat peraga yang digunakan pada kegiatan ini adalah alat peraga nomograf, alat peraga neraca timbang alat peraga mobil berjalan. Masing-masing alat peraga tersebut memberikan pemahaman konsep berhitung matematika pada operasi hitung penjumlahan, pengurangan, perkalian dan pembagian. Dari hasil post-test yang dilakukan tampak terjadi peningkatan pengetahuan siswa terhadap alat peraga dan pemahaman konsep dari pemecahan masalah operasi hitung matematika yang berupa operasi penjumlahan, pengurangan, perkalian dan pembagian setelah diberikan pemahaman dengan bantuan alat peraga matematika. 


\section{PENDAHULUAN}

Salah satu tugas pokok dan fungsi dosen pada perguruan tinggi adalah melaksanakan Tridarma Perguruan Tinggi diantaranya adalah melaksanakan pengabdian kepada masyarakat. Dalam Undang-undang Nomor 12 Tahun 2012 tentang Pendidikan Tinggi, pada pasal 47 ayat 1 menyatakan bahwa "pengabdian kepada mayarakat didefinisikan sebagai kegiatan sivitas akademika dalam mengamalkan dan membudayakan ilmu pengetahuan dan teknologi untuk memajukan kesejahteraan umum dan mencerdaskan kehidupan bangsa”.

Ilmu Matematika merupakan salah satu cabang ilmu pengetahuan yang mempunyai peranan yang sangat penting dalam kehidupan. Pelajaran matematika pada awalnya diperkenalkan kepada siswa dimulai dari taman kanak-kanak sampai dengan perguruan tinggi. Hal itu disebabkan matematika yang memiliki fungsi sebagai dasar untuk mempelajari ilmu-ilmu yang lain. Pencapaian nilai hasil belajar siswa Indonesia untuk bidang studi matematika masih cukup mengkhawatirkan.

Pada jenjang Pendidikan dasar, siswasiswi sangat perlu diberikan penanaman tenatng pengetahuan dasar matematika sebagai bekal mereka untuk menempuh jenjang Pendidikan yang lebih tinggi. Pada Pendidikan dasar ini konsep-konsep matematika dasar perlu ditanamkan sehingga siswa-siswi memiliki fondasi yang kuat untuk Pendidikan selanjutnya. Pendidikan dasar bertujuan untuk memberikan bekal kemampuan dasar kepada peserta didik untuk mengembangkan kehidupannya (Dahniar. et al., 2016).

Beberapa ahli mensinyalir, "kelemahan matematika pada siswa Indonesia karena pembelajaran matematika di sekolah ditakuti bahkan dibenci siswa" (Hartoyo, 2015). Padahal jika matematika dipelajari dengan sungguh-sungguh dan tidak ada rasa benci yang membuat mindset kita hanya ada rasa pesimis dalam mempelajari matematika maka kita akan bisa dan senang dengan matematika. Sikap negatif seperti ini muncul karena adanya persepsi bahwa pelajaran matematika yang sulit (Sirait, 2016). Memang banyak keluhan dari para siswa untuk bisa dengan mudah memahami pelajaran matematika ini. Dikarenakan juga adanya pengaruh dari orang lain yang sudah terlebih dahulu atau pernah mengikuti pelajaran matematika dan orang itu sulit untuk mengerti matematika ini sehingga persepsi orang tersebut dapat menjadi sugesti siswa ini. Sudah menjadi 
tugas seorang guru untuk membuat kegiatan belajar dan mengajar matematika bisa menjadi lebih menarik dan asyik di hadapan para siswa (Jaya, 2017).

Pembelajaran dengan menggunakan alat peraga terbukti dapat meningkatkan hasil belajar siswa dalam menyelesaikan soal cerita (Nurseto, 2012).

Tujuan penggunaan alat peraga dalam pembelajaran matematika adalah: (1) Memberikan kemampuan berpikir matematika secara kreatif, (2) Mengembangkan sikap yang menguntungkan ke arah berpikir matematika, (3) Menunjang matematika di luar kelas yang menunjukkan penerapan matematika dalam keadaan sebenarnya, (4) Memberikan motivasi dan memudahkan abstraksi, dan (5) Memberikan permasalahan-permasalahan menjadi lebih menarik bagi anak yang sedang melakukan kegiatan belajar. Pendapat ini memberikan informasi bahwa penggunaan alat peraga dalam matematika mampu mendorong seseorang berpikir kreatif, mengembangkan sikap berpikir matematis, memudahkan abstraksi, memotivasi belajar. Penggunaan alat peraga dalam pembelajaran juga membantu guru dalam menunjukkan kegunaan matematika dalam kehidupan sehari-hari dan memberikan permasalahan yang lebih menarik untuk diselesaikan oleh peserta didik (Suwardi et al., 2016).
Siswa sudah mencapai aspek pemahaman bila ia mengerti sesuatu, misalnya dengan menunjukkan contoh dan bukan contoh, dapat menjelaskan perbedaan antara dua hal juga termasuk aspek pemahaman.

Berdasarkan beberapa pengamatan yang menunjukkan bahwa matematika merupakan salah satu pelajaran yang menakutkan bagi siswa, bahkan banyak siswa yang menganggapnya sebagai ancaman dalam belajar. Kesulitan belajar matematika umumnya di sebabkan karena sifat dari matematika yang memiliki obyek abstrak yang boleh dikata berseberangan dengan perkembangan anak (Jamal, 2014). Selain itu pembelajaran matematika tidak lepas dari peran seorang guru. Untuk dapat menumbuhkan minat siswa dalam belajar, terutama matematika, diperlukan kreativitas seorang guru dalam bahan ajar. Antara komponen satu dan komponen lainnya yang terlibat dalam pendidikan diharapkan dapat saling menginspirasi sehingga pembelajaran matematika bisa lebih menyenangkan dan mengasyikkan (Gunawan et al., 2017).

Pada jenjang Pendidikan dasar Siswa akan lebih mudah mengingat dan memahami pembelajaran matematika jika siswa suka melakukan itu dan disertai dengan pengalaman nyata yang ada dalam kehidupan sehari-hari. Semua abstraksi yang berdasarkan kepada situasi dan 
pengalaman konkrit, prinsip penjelmaan banyak (Multiple embodiment Principal) adalah suatu prinsip yang bila diterapkan oleh guru untuk setiap konsep yang diajarkan akan menyempurnakan penghayatan siswa terhadap konsep itu (Marliani \& Hakim, 2015). Jika seorang siswa SD ikut dalam pembelajaran tersebut maka siswa akan merasa senang dan tidak bosan. Antusiasme siswa untuk belajar akan meningkat. Melalui permainan ini siswa diajak untuk terlibat langsung dalam pembelajaran sehingga anak-anak tanpa disadari dapat menerapkan konsep dalam belajar matematika.

Ilmu Matematika seringkali dianggap momok bagi siswa, karena masih banyak siswa yang menganggap sebagai mata pelajaran yang sulit dan membingungkan, tetapi kenyataannya matematika akan sangat menarik antusias siswa jika dihadirkan pembelajaran yang menarik seperti permainan (Sirait, 2016). Dalam pembelajaran matematika terdapat beberapa cara yang dapat diterapkan agar membuat matematika menjadi pelajaran yang mudah dan menyenangkan. Salah satu caranya adalah menyajikan materi pelajaran dengan menggunakan media pembelajaran alat peraga yang diharapkan dapat meningkatkan prestasi belajar. Pembelajaran menggunakan alat peraga ini dilatarbelakangi adanya strategi belajar yang memberikan kesempatan kepada siswa untuk aktif belajar, dengan cara merubah metode pembelajaran yang berpusat pada guru (teacher oriented) menjadi berpusat pada siswa (student oriented).

Dari uraian di atas, maka dalam kegiatan pengabdian masyarakat ini akan memberikan pengenalan alat peraga dasar matematika kepada siswa sekolah dasar (SD) di Kecamatan Pamulang Kota Tangerang Selatan.

\section{METODE}

Pengabdian masyarakat ini dilaksanakan selama 2 hari pada tanggal 9 dan 10 desember 2019 dengan sasaran siswa siswi Sekolah Dasar (SD) di kecamatan Pamulang, kota Tangerang Selatan.

Metode yang digunakan pada kegiatan pengabdian kepada masyarakat ini adalah memberikan praktek secara langsung kepada siswa-siswi tentang alat peraga matematika dasar yang akan dipandu oleh narasumber. Praktek ini akan dilakukan secara berkelompok dan bergantian dengan didampingi oleh tim dosen pengabdi. Dengan praktek secara langsung terhadap penggunaan alat peraga matematika dasar ini diharapkan dapat menumbuhkan minat siswa dalam belajar matematika.

Kegiatan ini menggunakan metode ceramah dan demonstrasi (praktek) yaitu : 
1. Metode ceramah digunakan di awal kegiatan yaitu memberikan penjelasan kepada siswa tentang materi matematika dasar dan cara penggunaan alat peraga yang berhubungan dengan materi. Kemudian siswa diberikan beberapa contoh masalah yang dapat diselesaikan dengan menggunakan alat peraga.

2. Metode demonstrasi (praktek) diberikan kepada siswa agar siswa berlatih atau mempraktekkan secara mandiri sesuai materi yang diberikan.

Pada awal kegiatan siswa diberikan test awal (pre-test) untuk mengetahui pengetahuan siswa terhadap alat peraga, yang kemudian diberikan perlakuan berupa pengenalan alat peraga dan pemberian masalah-masalah dengan menggunakan alat peraga matematika.

Indikator yang digunakan untuk mengukur pengetahuan awal siswa yaitu secara deskriptif mengetahui :

1. Apakah siswa pernah mengenal alat peraga matematika.

2. Bagaimana siswa belajar matematika selama ini.

3. Bagaimana hasil belajar matematika siswa saat ini berdasarkan nilai-nilai yang telah diperoleh.

Sebagai tahapan akhir dilakukan test lanjutan (post-test) untuk mengetahui perkembangan pengetahuan siswa terhadap alat peraga matematika. Kegiatan ini menawarkan pembelajaran matematika dengan menggunakan alat peraga matematika dimana pembelajaran matematika ini dirancang dengan menggunakan masalah-masalah konsep dasar yang dekat dengan kehidupan dunia siswa. Alat peraga matematika yang akan digunakan diantaranya adalah: Garis bilangan, Nomograf, Jam sudut, Neraca Timbang yang kesemuanya adalah mengenai konsep bilangan dalam matematika.

\section{Realisasi Pemecahan Masalah}

Alat peraga garis bilangan yang dinamakan "Mobil Berjalan" ini adalah sebagai berikut: terlebih dahulu harus dibuat kesepakatan dengan murid. Kesepakatan pertama adalah: untuk bilangan yang sebelah kanan dari depan adalah bilangan positif dan sebelah kiri adalah bilangan negatif. Ketika bilangan operasi hitung ada di bilangan positif, maka arah mainan mobil ini menghadap ke bilangan positif. Ketika bilangan operasi hitung ada di bilangan negatif, maka mainan mobil menghadap ke arah bilangan negatif. Kesepakatan kedua: Jika operasi hitung penjumlahan maka mobil berjalan ke depan. Jika operasi hitung pada bilangan bulat pengurangan, maka mobil akan berjalan mundur. 


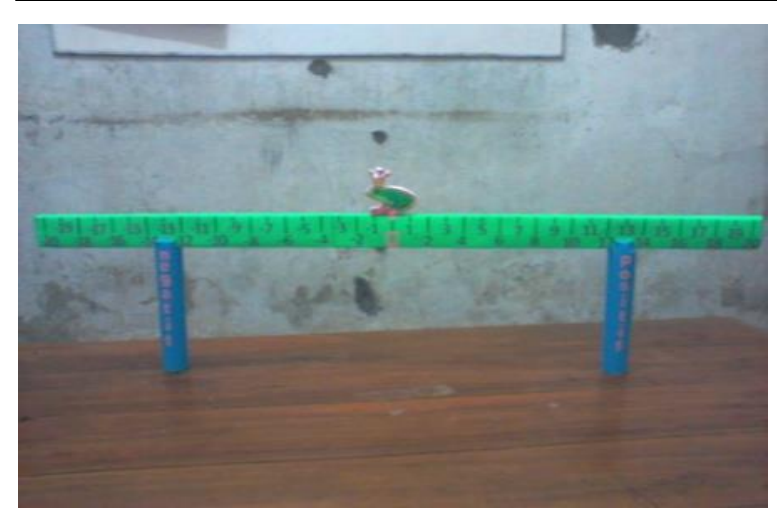

Gambar 1. Alat Peraga Mobil Berjalan

Nomograf dapat digunakan sebagai alat peraga matematika yang dapat digunakan untuk :

1. Menjumlahkan dua bilangan bulat $(\mathrm{a}+$ $\mathrm{b}=\mathrm{c})$

2. Mengilustrasikan bahwa jumlah setiap bilangan bulat dan lawannya sama dengan $0(a+(-a)=0)$

3. Mengilustrasikan sifat komutatif penjumlahan

4. Menghubungkan pengurangan bilangan

- bilangan bulat penjumlahan.

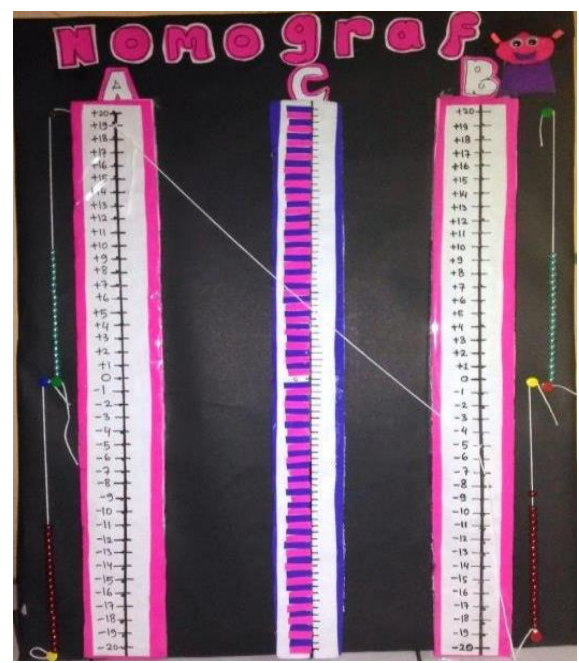

Gambar 2. Alat Peraga Nomograf
Timbangan bilangan hanya digunakan untuk angka dengan nilai kecil. Lengan timbangan di sebelah kiri dan kanan harus seimbang, dan berat masing-masing anak sama. Hasil operasi angka (jawaban) benar jika skala keseimbangan kiri dan kanan seimbang. Jawabannya ditunjukkan oleh angka yang tercetak di lengan kanan timbangan tempat timbangan digantung di posisi timbangan.

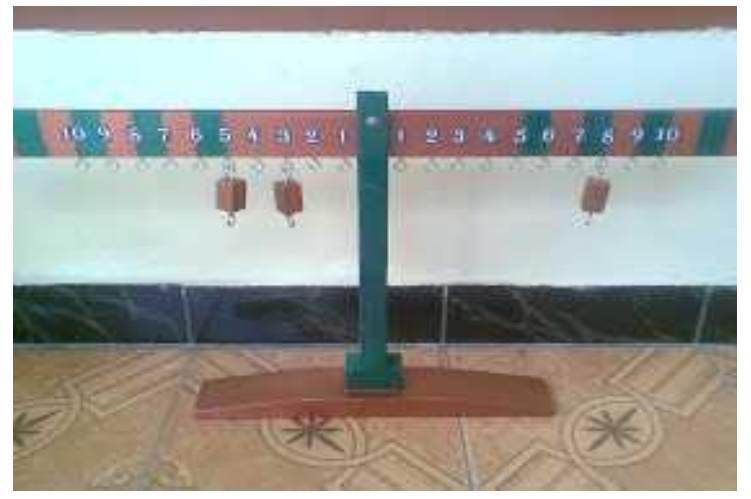

Gambar 3. Alat Peraga Neraca Timbang

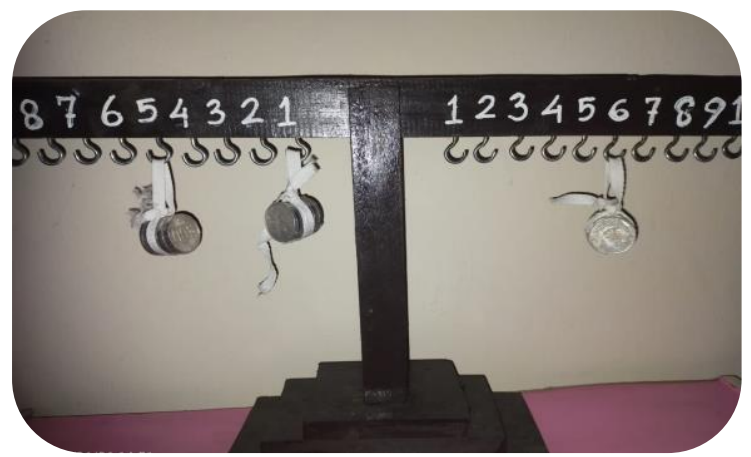

Gambar 4. Alat Peraga Neraca Timbang

Cara Penggunaan Neraca Timbang adalah sebagi berikut:

1. Operasi Hitung Penjumlahan

(Contoh: $3+5=8$ ) 
Gantungkan sebuah anak timbangan pada angka 3 dan 5 di lengan sebelah kiri. Untuk menunjukkan hasil penjumlahan tersebut, dapat dicoba menggantungkan sebuah anak timbangan pada lengan sebelah kanan sampai kedua lengan timbangan seimbang. Ternyata setelah anak timbangan digantungkan di angka 8 pada lengan sebelah kanan, maka timbangan akan seimbang. Sehingga kesimpulannya $3+5=8$.

2. Operasi Hitung Pengurangan (Contoh: $9-3=6$ )

Untuk menunjukkan hasil pengurangan 9 - 3, dapat dicoba dengan cara menggantungkan sebuah anak timbangan di angka 9 pada lengan sebelah kanan. Selanjutnya gantungkan sebuah anak timbangan di angka 3 pada lengan sebelah kiri. Lalu dengan mencoba-coba, gantungkan sebuah anak timbangan pada lengan sebelah kiri sampai kedua lengan timbangan seimbang. Ternyata setelah anak timbangan digantungkan di angka 6 pada lengan sebelah kiri, maka timbangan akan seimbang. Sehingga kesimpulannya $9-3=6$.

3. Operasi Hitung Perkalian

(Contoh: 2 × $3=6$ )

Gantungkan tiga buah anak timbangan di angka 2 pada lengan sebelah kiri.
Untuk menunjukkan hasil perkalian $2 \mathrm{x}$ 3, dapat dicoba dengan cara menggantungkan sebuah anak timbangan pada lengan sebelah kanan sampai kedua lengan timbangan seimbang. Ternyata setelah anak timbangan digantungkan di angka 6 pada lengan sebelah kanan timbangan akan seimbang. Kesimpulannya 2 x $3=$ 6.

4. Operasi Hitung Pembagian

(Contoh: $8: 2=4$ )

Gantungkan sebuah anak timbangan di angka 8 pada lengan sebelah kanan. Untuk menunjukkan hasil operasi pembagian $8: 2$, dapat dicoba menggantungkan 2 buah anak timbangan sekaligus pada lengan sebelah kiri sampai kedua lengan timbangan seimbang. Ternyata setelah kedua anak timbangan digantungkan di angka 4 pada lengan sebelah kiri, maka timbangan akan seimbang. Kesimpulannya $8: 2=4$

\section{HASIL}

Pre test yang diberikan kepada siswa menunjukkan bahwa belum mengenal alat peraga yang dibawa tim pengabdi. Siswa dalam mengikuti kegiatan pengabdian dan melihat alat peraga sangat antusias.

Simulasi yang dilakukan oleh tim pengabdi dapat dipahami dengan baik oleh 
siswa. Siswa juga aktif bertanya saat tidak memahami atau meminta tim pengabdi untuk mengulangi kegiatan.

Post test yang dilakukan menunjukkan bahwa siswa lebih bisa memahami materi operasi matematika dengan lebih baik dibandingkan sebelum menggunakan alat peraga edukatif.

\section{PEMBAHASAN}

Tahapan evaluasi awal berupa pre-test dilakukan untuk mengetahui seberapa kenal siswa terhadap alat peraga yang akan dibawakan pada materi kali ini dan bagaimana siswa belajar matematika selama ini. pre-test ini dilakukan dalam bentuk pertanyaan yang ditanyakan oleh tim dosen kepada siswa sebelum memulai kegiatan ini. Dari hasil pre-test menunjukkan bahwa seluruh siswa belum mengenal alat peraga yang dibawakan pada kegiatan ini dan mereka selama ini belajar matematika langsung kepada teori-teori yang ada tanpa diberikan pemahaman dengan bantuan alat peraga (Sari et al., 2018). Jika dilihat dari nilai-nilai matematika siswa kemampuan awal matematika siswa masih kurang dalam pemecahan-pemecahan masalah secara langsung.

Tahapan evaluasi akhir kegiatan ini adalah dalam bentuk post-test yang dilakukan seperti pada pre-test untuk mengetahui apakah ada perubahan dari hasil evaluasi pre-test. Hasil post-test ini dibandingkan dengan hasil pre-test yang telah dilakukan sehingga akan diketahui sejauh mana pengenalan siswa terhadap alat peraga dan ada tidaknya pengaruh pemahaman siswa (Jamiludin et al., 2020).

Dari hasil post-test yang dilakukan tampak terjadi peningkatan pengetahuan siswa terhadap alat peraga dan pemahaman konsep dari pemecahan masalah operasi hitung matematika yang berupa operasi penjumlahan, pengurangan, perkalian dan pembagian setelah diberikan pemahaman dengan bantuan alat peraga matematika.

Dari kegiatan pengenalan alat peraga matematika yang dilakukan siswa menjadi dapat membedakan operasi bilangan dan tanda bilangan. Operasi penjumlahan (+) berbeda dengan tanda positif (+) dan operasi pengurangan () berbeda dengan tanda (-).

Salah satu hasilnya adalah siswa memahami bahwa misalnya: $2+3=5$ artinya bilangan ini adalah positif, maka mobil menghadap ke positif, kemudian maju 2 langkah, terus melangkah lagi 3 langkah sehingga berhenti di bilangan 5 .

Contoh lain : $3+(-5)=-2$, siswa memahami bahwa artinya mobil menghadap ke positif kemudian melangkah 3 langkah. Karena dijumlahkan dengan -5, maka mobil menghadap ke negatif, kemudian melanjutkan langkahnya sebanyak 5 
langkah, sehingga mobil berada di bilangan -2 .

Misalnya lagi: $4+3=7$ artinya bilangan ini adalah positif, maka mobil menghadap ke positif, kemudian mobil melangkah maju 4 langkah, dari bilangan 4 mobil melangkah lagi 3 langkah sehingga berhenti di bilangan 7 .

\section{SIMPULAN}

Pengenalan alat peraga dasar matematika kepada siswa Sekolah Dasar (SD) ini menjadikan siswa memiliki pengetahuan bahwa belajar matematika tidak hanya secara teori saja, akan tetapi banyak alat peraga yang menarik yang dapat digunakan siswa dalam belajar sehingga sedikit demi sedikit siswa akan merubah anggapan bahwa matematika adalah pelajaran yang menakutkan menjadi pelajaran yang menyenangkan. Selain itu alat peraga ini, juga memudahkan siswa dalam menangkap materi bilangan

\section{SARAN}

Hasil kegiatan yang dilakukan menunjukkan terjadi peningkatan pengetahuan siswa terhadap alat peraga dan pemahaman konsep dari pemecahan masalah operasi hitung matematika yang berupa operasi penjumlahan, pengurangan, perkalian dan pembagian setelah diberikan pemahaman dengan bantuan alat peraga matematika diharapkan guru dapat melanjutkan memberikan materi dengan alat bantu peraga dan membuat alat peraga lainnya.

\section{UCAPAN TERIMA KASIH}

Tim pengabdi mengucapkan terima kasih kepada Universitas Pamulang, Kepala SD di Kecamatan Pamulang Tangerang sebagai mitra, dan seluruh siswa-siswi yang megikuti kegiatan pengabdian ini.

\section{DAFTAR PUSTAKA}

Dahniar., Murdiana, I. N., \& Sukayasa. (2016). Penggunaan Alat Peraga Untuk Meningkatkan Hasil Belajar Siwa Kelas 1 SD Negeri 6 Tolitoli dalam Menyelesaikan Soal Cerita Tentang Penjumlahan Dan Pengurangan. Jurnal Kreatif Tadulako Online, 4(3), 165-177.

Gunawan, I., Ulfatin, N., Sultoni, S., Sunandar, A., Kusumaningrum, D. E., $\&$ Triwiyanto, T. (2017).

Pendampingan Penerapan Strategi

Pembelajaran Inovatif dalam Implementasi Kurikulum 2013. Abdimas Pedagogi, 1(1), 37-47. Hartoyo, A. (2015). Pembinaan karakter dalam pembelajaran matematika. Math Didactic: Jurnal Pendidikan Matematika, 1(1), 8-22. https://doi.org/10.33654/math.v1i1.90 
Jamal, F. (2014). Analisis Kesulitan

Belajar Siswa Dalam Mata Pelajaran

Matematika Pada Materi Peluang

Kelas XI IPA SMA Muhammadiyah

Meulaboh Johan Pahlawan. Jurnal

MAJU (Jurnal Pendidikan

Matematika), 1(1), 18-36.

http://www.ejournal.stkipbbm.ac.id/in

dex.php/mtk/article/view/232

Jamiludin, J., Darnawati, D., Uke, W. A.

S., \& Ayu, A. P. (2020). Pelatihan

Media Kahoot pada Guru dalam

Proses Evaluasi Belajar. Amal Ilmiah :

Jurnal Pengabdian Kepada

Masyarakat, 1(2), 63-67.

Jaya, H. N. (2017). Keterampilan Dasar

Guru untuk Menciptakan Suasana

Belajar yang Menyenangkan. Jurnal

Pendidikan dan Ilmu Pengetahuan,

17(1), 23-35.

http://103.114.35.30/index.php/didakti

s/article/view/1555/1275

Marliani, N., \& Hakim, A. R. (2015).

Pengaruh Metode Belajar Dan

Kecemasan Diri Terhadap Hasil

Belajar Matematika Peserta Didik.

JKPM (Jurnal Kajian Pendidikan

Matematika), 01(01), 136-150.

Nurseto, T. (2012). Membuat Media

Pembelajaran yang Menarik. Jurnal

Ekonomi dan Pendidikan, 8(1), 19-35.

https://doi.org/10.21831/jep.v8i1.706

Sari, D. A., Rahayu, C., \& Widyaningrum,
I. (2018). Pembelajaran Matematika Menggunakan Model Contextual Teaching and Learning (CTL) pada Materi Kubus dengan Konteks Tahu di kelas VIII. Journal of Dedicators Community, 2(2), 108-115. https://doi.org/10.34001/jdc.v2i2.704

Sirait, E. D. (2016). Pengaruh Minat Belajar Terhadap Prestasi Belajar Matematika. Formatif: Jurnal Ilmiah Pendidikan MIPA, 6(1), 35-43. https://doi.org/10.30998/formatif.v6i1. 750

Suwardi, S., Firmiana, M. E., \& Rohayati, R. (2016). Pengaruh Penggunaan Alat Peraga terhadap Hasil Pembelajaran Matematika pada Anak Usia Dini. JURNAL Al-AZHAR INDONESIA SERI HUMANIORA, 2(4), 297. https://doi.org/10.36722/sh.v2i4.177 